\title{
THE IMPACT OF OPERATION OF ELASTOMERIC TRACK CHAINS ON THE SELECTED PROPERTIES OF THE STEEL CORD WIRES
}

\section{WPEYW EKSPLOATACJI GĄSIENIC ELASTOMEROWYCH NA WYBRANE WŁASNOŚCI DRUTÓW STALOWEGO KORDU*}

\begin{abstract}
The track running systems enable movement of heavy vehicles on unpaved and rough terrain, snow-covered, marshy or swampy surfaces, as well as overcoming natural or artificial barriers. The important structural component of the elastomeric tracks is a steel cord sunk in the elastomer creating the tread with the purpose of stiffening the structure, maintaining its proper deflection and giving the adequate resistance to tensile forces. The results of the studies presented in the work have shown that operation of the elastomeric track chains in conditions where they are continuously exposed to contact with foundation, frequent braking and bumping against roughness lead to damage of the steel cord material and a change in its mechanical properties.
\end{abstract}

Keywords: elastomeric track, cord, pearlitic steel.

\begin{abstract}
Gąsienicowe układy bieżne umożliwiaja poruszanie się ciężkich pojazdów po powierzchniach nieutwardzonych oraz w trudnym terenie, zaśnieżonym, bagnistym lub grząskim, a także pokonywanie przeszkód naturalnych i sztucznych. Ważnym elementem konstrukcyjnym gasienic elastomerowych jest stalowy kord, zatopiony w elastomerze tworzacym rzeźbę bieżnika, ma on na celu usztywnienie konstrukcji, zachowanie jej właściwego ugięcia oraz nadanie odpowiedniej odporności na siły rozciagające. Wyniki badań prezentowanych w pracy wykazaly, że eksploatacja gasienic elastometrowych $w$ warunkach, $w$ których narażone sa na ciągła styczność z podtożem, częste hamowanie oraz uderzenia w nierówności prowadzi do uszkadzania materiału stalowego kordu i zmiany jego własności mechanicznych.
\end{abstract}

Stowa kluczowe: gasienica elastomerowa, kord, stal perlityczna.

\section{Introduction}

The track running systems enable movement of heavy vehicles on unpaved and rough terrain, snow-covered, marshy or swampy surfaces, as well as overcoming natural or artificial barriers $[5,7,28]$. This is possible by distributing the vehicle mass on greater surface which causes significant drop in unit pressure, increase in adherence of a vehicle and achieving greater driving force. The systems also improve quality of operation and maneuvering a vehicle in the difficult terrain conditions by reducing the rolling resistance and the tendency of a vehicle to sink.

The track is a closed band girding wheels and rolls of the track running system on the circumference of which four zones can be distinguished: the upper one rolled over tension rollers, the retaining one cooperating with the ground, since it determines the size of the resulting driving force necessary for the motion of the vehicle, and the two inclined ones contained between one of the support wheels and the drive wheel, as well as the carrier wheel and the directional wheel $[5,28]$. The track chain bears all forces, vertical, longitudinal and transverse, appearing in contact of a vehicle with foundation. Due to the construction the metal, rubber-metal and elastomer tracks can be distinguished.

The elastomeric tracks are designed on the principle of the inner chain created by links responsible for carrying the drive from the driving wheel and preventing sliding the track off $[5,7,28]$. Additionally, the track is reinforced with steel cord sunk in elastomer creating the tread pattern aimed at stiffening the structure, maintaining its proper deflection and giving the proper resistance to tensile forces.
The cord is a structure composed of strands created by several intertwined individual wires. The cord may also be the strand itself made of several wires $[3,11,16,19,20]$. Individual wires have diameters from 0,15 to $0,38 \mathrm{~mm}$, are produced as brass or zinc plated wires and have the following properties $[16,18,19,20]$ :

- very high dynamic module,

- high stiffness,

- high strength,

- low creep capacity,

- high compressive modulus,

- dimensional stability,

- high resonance frequencies.

Wires designated for production of steel cord reinforcing tracks are manufactured from unalloyed pearlitic steel. The pearlitic steels containing from about 0,70 to $0,95 \% \mathrm{C}$ belong to the group of unalloyed steels of the quality class designated for cold drawing or rolling $[1-3,8,11,18,20]$. Their chemical composition and mechanical properties are in compliance with the PN-EN 10323:2006 (U) standard [12]. As standard the steel wires for cord are characterised with tensile strength within the range of 2573 to even $4116 \mathrm{MPa}$ $[11,16]$.

One of the problems widely discussed in the subject literature is cracking of the pearlitic steel subjected to plastic working and during its operating $[4,18,10,14,16]$. The problem is the more serious that it concerns many industrial branches where the steel cord is applied and therefore it has been the subject of years of research conducted in numerous scientific centres all over the world [14, 25, 26, 31].

(*) Tekst artykułu w polskiej wersji językowej dostępny w elektronicznym wydaniu kwartalnika na stronie www.ein.org.pl 
The fatigue strength of steel wires greatly depends on metallurgical purity of the material, and especially on content of oxygen, silicon and sulphur. Presence of non-metallic inclusions in steel strongly decreases the fatigue resistance as it is around the impurities that the strong accumulation of stresses appear leading in effect to component cracking $[1,4,11,16,20]$.

According to Golis [16] the maximum permissible content of nonmetallic inclusions in unalloyed pearlitic steel of the D75, D78, D80 and D83 grades designated for production of cord wires should not exceed the size of the standard No. 2 according to EN 10247:2007 standard. The non-metallic inclusions, especially including those of minimum plasticity such as oxides or brittle silicates, cause lowering of the wire ductility hindering the technological processes. Presence of the inclusions constitutes the main reason for lowering the degree of the material deformation.

The research performed by Zelin [30] have shown that as a result of elastic deformations preceding the permanent plastic deformation of the material, the horizontal micro delamination of the single lamellae of cementite takes place. The changes were observed both, at tension and twisting of the wires. In the course of increasing the applied force the coalescence of the created micro delaminations follows and the cracking propagation resulting with decohesion of the whole component.

Sauvage and Ivanisenko [21, 22, 29] have shown that the cause of cracking of pearlitic steel subjected to plastic working is segregation of carbide precipitations at the phase boundaries. The studies have confirmed the theory earlier described by Gridnev and Gavriluk $[15,17,20]$, according to which as a result of plastic deformation the carbon atoms occupy vacancies appearing in the cementite lattice, increasing by that the concentration of carbon atoms at the phase boundary ferrite-cementite and, as a consequence, resulting in brittleness of those structures. Both teams have shown the simple relation between the degree of plastic deformation and the susceptibility of the pearlitic steel to cracking. The deformation increase is accompanied by increase in the density of lattice defects and thus the intensity of carbide segregations at phase boundaries increases.

The structural analysis performed by Izotov et al. [23, 24] have unequivocally shown that cracking of the cementite lamellae follows as a result of dislocations pile-up at the phase boundary between ferrite and cementite precipitations. As a result of the applied force the movement of edge dislocations in the ferrite precipitation follows, as well as dislocation of crystal fragments over the slip planes and because the fact that each ferrite lamella has different crystallographic orientation the dislocations are crossing at the cementite lamellae initiating finally creation of microcracks. The studies have confirmed the earlier literature reports, the works of Langeford, Wilson, Embury and Fisher [12, 13, 31] indicating that in the course of plastic deformation of pearlitic steel it is just on the cementite lamellae that the strongest concentration of lattice defects appears which, in the consequence is the cause of cracking of these structural components.

The different theory explaining the mechanism of cementite lamellae cracking was presented by Languillaume et al. [27]. According to his research, as a result of plastic pearlite deformation the uncontrolled, very strong increase in energy at the contact of both phases takes place, i.e. in the inter-lamellar spaces of pearlite. The observed increase in energy leads to thermodynamic destabilisation of cementite resulting in cracking of its lamellae. The results of this research have been confirmed many times by the other research teams including Danoix and Sauvage [9, 29, 31].

\section{Purpose and object of the tests}

The elastomeric track chains of mini excavators are exposed during operation to continuous contact with base, frequent breaking and numerous strokes against roughness. Such working conditions may lead to damaging the material of the steel cord constituting stiffening of the track structure and, as a consequence, to a change in its functional properties. The results of questionnaires conducted among Lower Silesian companies of general building have shown that the average life of the elastomeric tracks applied in mini excavators is about 825 moto-hours, and the most frequent cause of their damage is rupture of the steel cord resulting in breaking continuity of the tread (Fig. 1).

The fractographic tests of wires from the defective steel cord performed using the scanning electron microscope have shown the presence of surfaces indicating for fatigue character of the damage (Fig.2). The fatigue part of the fracture was smooth with the characteristic fatigue striae arranged almost parallel to the direction of crack development. The fracture origin was localised at the external edge of the wire, i.e. in the area of the highest accumulation of the complex operating stresses. At the external circumference of the wire fractures the immediate zone of the plastic character and the expanded surface topography were visible. Thus, the results of those analyses have shown that damages were not created as a result of the operating overload of the tracks, but as a result of another factors causing decrease in the fatigue strength in the cord wires.

The research results presented in the work aimed to determining the impact of the elastomeric track operation in general purpose mini excavators on structure and selected mechanical and technological properties of the pearlitic steel applied to the wires of their cord.

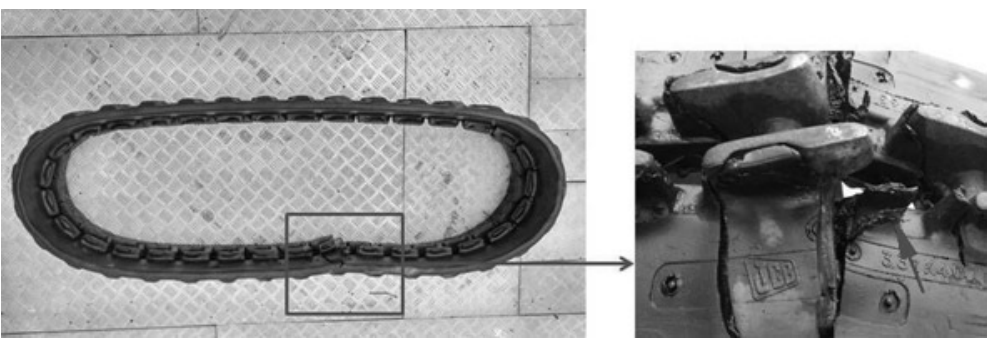

Fig. 1. Defective elastomeric track coming from mini excavator model 8018 CTS from $J C B$. Visible fragment of the steel cordu, which punched the layer of rubber and led to damaging the tread (see arrow)

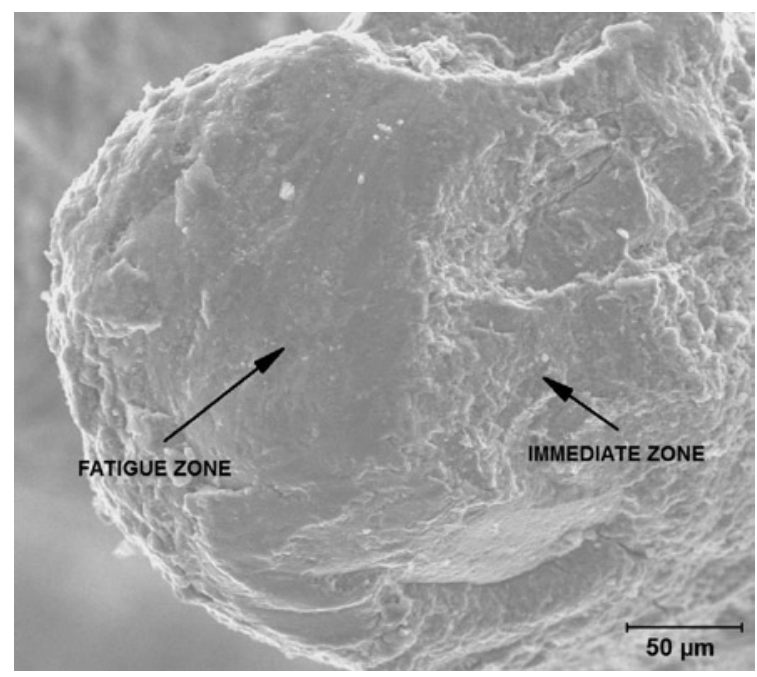

Fig. 2. Microscopic image of fatigue fracture of the wire coming from the track shown in Fig. 1. Visible smooth fatigue zone and the IMMEDIATE ZONE of the expanded surface topography. SEM 


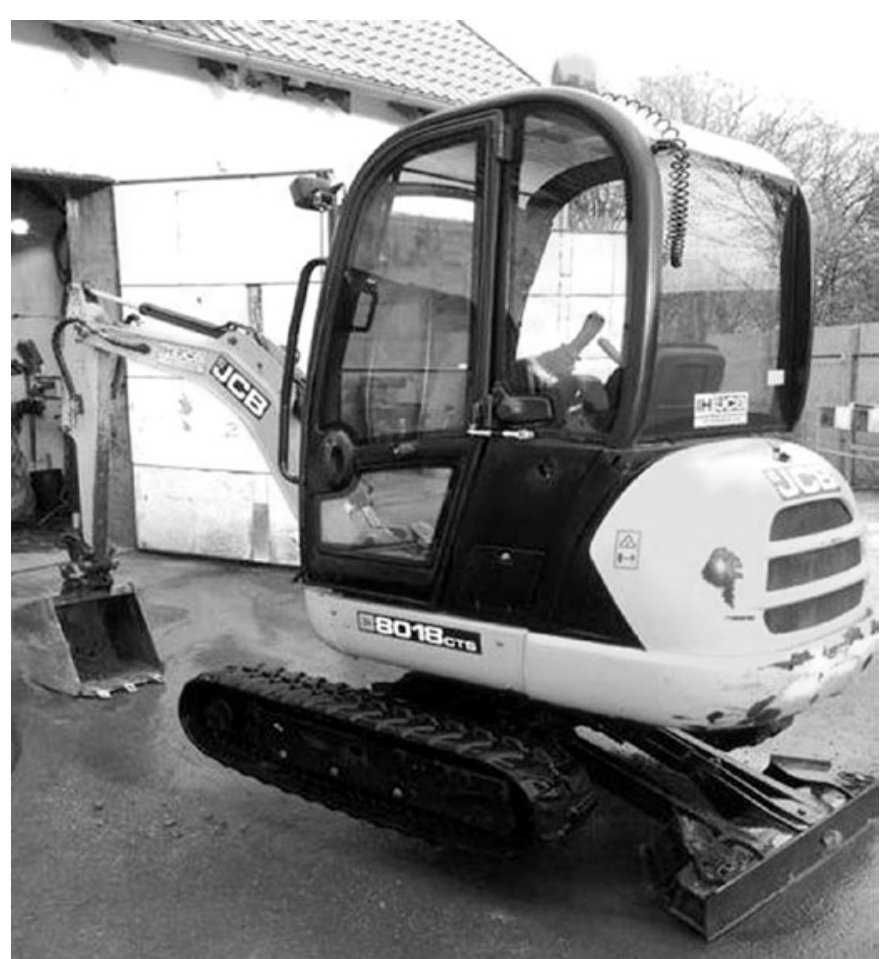

Fig. 3. Mini excavator model 8018 CTS from JCB, from which the tested elastomeric tracks came

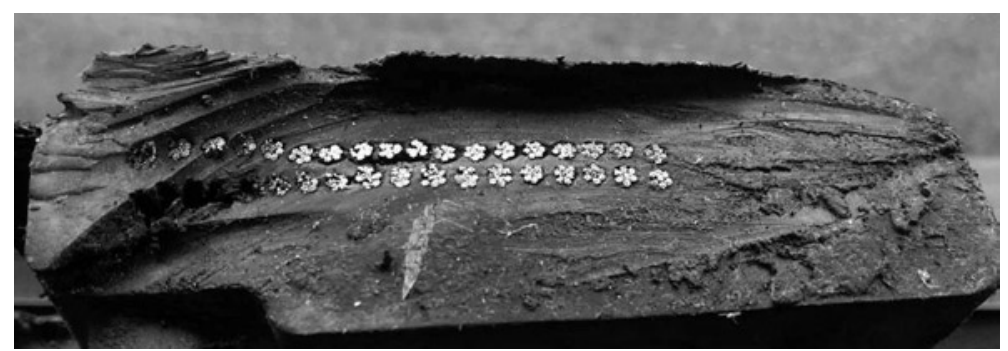

Fig. 4. Schematic diagram of the steel cord shown in Fig. 3, visible seven strands of 0,9 $\mathrm{mm}$ in diameter

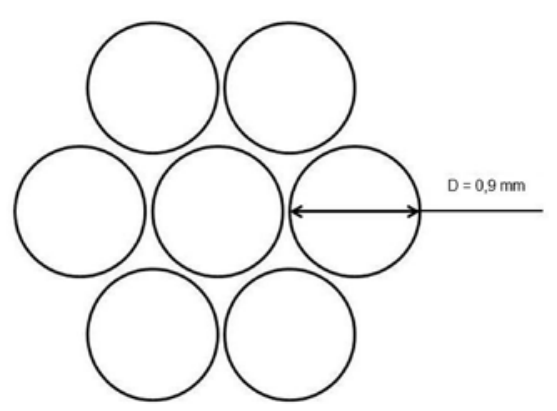

The object of the research were two elastomeric track chains of the $332 /$ L5153 type coming from mini excavators from JCB, model 8018 CTS (Fig. 3). The tested tracks were differing with the degree of wear, the track No. 1 was the new sample,

Fig. 5. Schematic diagram of the steel cord shown in Fig. 3, visible seven strands of $0,9 \mathrm{~mm}$ in diameter.

without operation, and the track No 2 was the sample in the afteroperation state used for the general building for the period of 1228 moto hours.

For evaluating the impact of elastomeric track operating on structure and the selected mechanical properties of pearlitic steel the wire samples of $\mathrm{d}=0,3 \mathrm{~mm}$ diameter were collected from the steel cord. Macroscopic tests of the type of the applied reinforcement have shown that in all tracks 36 lines of the steel cord appear arranged in two parallel layers of 18 lines each (Fig. 4). Each of the cord lines is built of 7 identical strands of $0,9 \mathrm{~mm}$ diameter. One of them is a core on which the remaining strands are wrapped in the form of one layer (Fig. 5). A line of the cord is wrapped in the right direction. All strands are built of 12 wires of $0,3 \mathrm{~mm}$ in diameter and consist of one convolution wire and two layers wrapped. The strand is made with wrapping in the left direction.

For microscopic tests in the etched and non etched states the NIKON ECLIPSE MA200 light microscope with the NIS Elements BR software was used, and the observations were conducted at magnification from $100 \mathrm{x}$ to $1000 \mathrm{x}$. The observations of microstructures of the tested steel were performed also with application of the JEOL JSM 6610 A scanning electron microscope at magnifications from $1000 \times$ to $10000 \times$. In course of the studies the accelerating voltage of 15 and $25 \mathrm{kVW}$ was used. The observations were conducted in the material contrast using the SE detectors.

Hardness measurements of the specimens were performed with the Vickers method with the use of the MMT-X3 micro hardness meter in conditions complying with the PN-EN ISO 6507-2:1999 standard. The measurement time was $15 \mathrm{~s}$ and the load was $500 \mathrm{~g}$.

The static tensile test was performed in conditions compliant with the PN-EN ISO 6892-1:2010 standard. The tests were performed at the MTS 858 Mini Bionix type testing machine. The specimens were made of wire of the initial measurement length $\mathrm{L}_{0}=100 \mathrm{~mm}$. The tensile tests were performed with constant stretching rate controlled by the rate of straining (method A according to the standard) and amounting to $\mathrm{e}_{\mathrm{Lc}}=0,00671 / \mathrm{s}$ until the rupture. The basic strength

properties of the material were determined: the tensile strength $\mathrm{R}_{\mathrm{m}}$ and necking $\mathrm{Z}$.

Analysis of technological properties involved the test of unidirectional turning and the test of bidirectional contraflexure of wires taken from the cord. The test of unidirectional turning was performed in conditions compliant with the PN-ISO 7800:1996 standard, which is the trial aimed at determining suitability of the material to the production processes. It involves turning the loaded wire around its own axis in one direction until rupture of the specimen. The tested specimens had length in accordance with the PN-ISO 7800:1996 standard and the applied load did not exceed $2 \%$ of the nominal load breaking the wire.

The trial of bidirectional contraflexure according to PNISO 7801: 1996 is applied to determining the resistance of wires to plastic deformations. It involves multiple bidirectional contraflexure of a specimen by the angle of $90^{\circ}$ around rolls of diameters defined in the PN-ISO 7801: 1996 standard. Both tests were performed with constant rate until fracture, the measurements were performed in the ambient temperature.

\section{The test results}

The macroscopic tests of the track No. 1 have shown that the contact surface of the track with foundation was ideally flat and the remnants of the production process were observed at surface of the trade in the form of linear shoulders (Fig. 6). Edges of the tread of the tested track were ended sharply and walls of the segments were uniform. Material of which the tested component was made was uniform and did not show symptoms of ageing and thickness of the tread was about $47 \mathrm{~mm}$.

The macroscopic tests of the track No. 2, in the after-operating condition have shown that it bears significant traces of wear resulting from utilizing of the machine. At its working surface many changes and damages resulting from direct contact with hard basement have been observed (Fig. 7). Edges of the tread were significantly rounded, which influences the decreased traction of the machine during maneuvering in the slushy terrain. Another trace of operating were losses in the form of ripped pieces of rubber as well as cuts and undercuts 


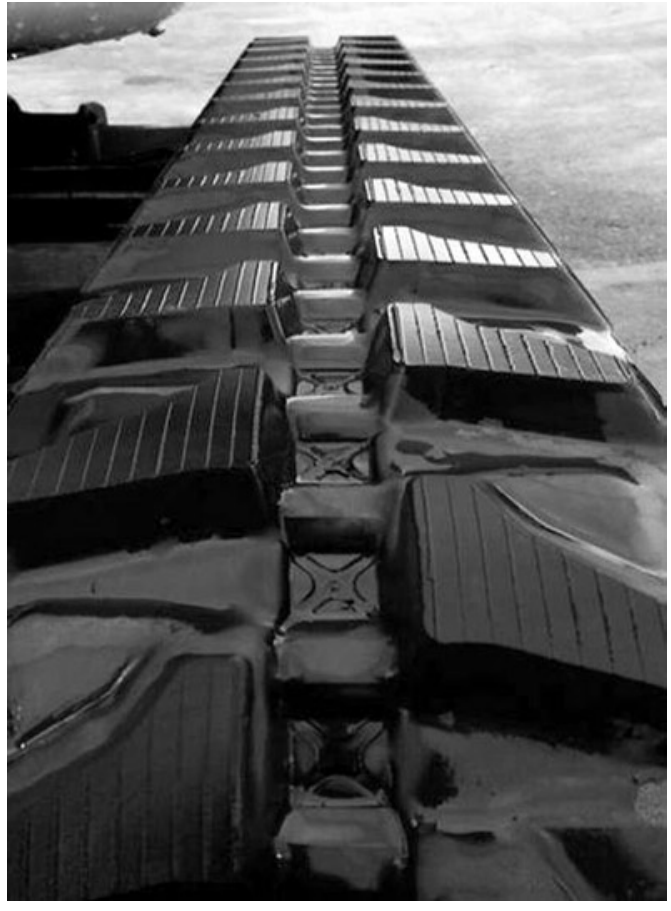

Fig. 6. The elastomeric track No. 1, the non-operated specimen. There are no cracks and damages at its surface, the tread edges are sharp and the segment walls are uniform, Visible remnants ot the production process in the form of linear shoulders

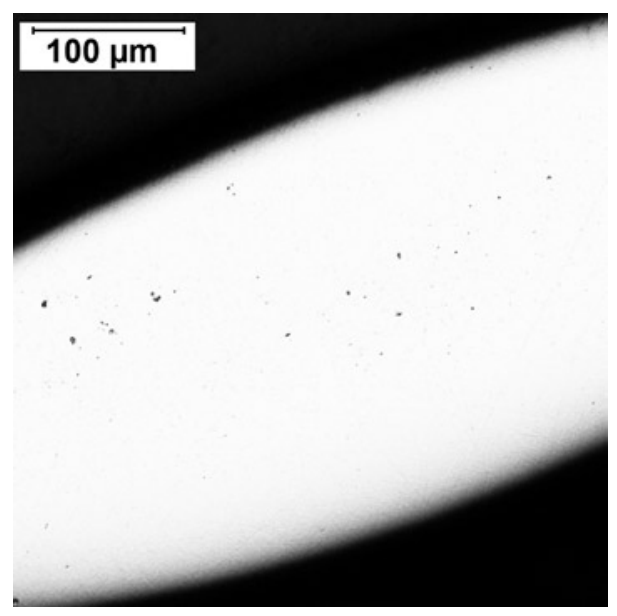

Fig. 8. Material of the cord wire from track No. 1, visible oxide non-metallic inclusions in the quantity equal to the standard 3 according to the PN-64/H-04510 standard. Non-etched state. Longitudinal section. LM

of the tread. The most important, and at the same time the most dangerous, symptom of the track wear were visible transverse cracks created as a result of maneuvering the vehicle around its own axis at the hard, e.g. concrete or asphalt surface. The surface of the tested track was porous and borne the traces of rubber ageing, its thickness amounted to about $40 \mathrm{~mm}$.

Microscopic observations of the material of the tested wires performed in the non-etched state have shown presence of large amount of non-metallic inclusions, mainly in the form of oxides. The impurities were distributed punctually and appeared in the number from the standard 3 to 4 according to the EN 10247:2007 standard, which, according to the subject literature data $[11,16,20]$ exceeds the maximum permissible content of non-metallic inclusions in the pearlitic steel designated for production of cord wires (Fig. 8 and 9). Fatigue strength of steel wires is greatly dependent on metallurgical purity of the material. Presence of that large number of non-metallic inclusions, especially in the form of brittle oxides, may cause lowering of material ductility making the technological processes difficult, and in particular cases leading even to cracking of the wires during operation.

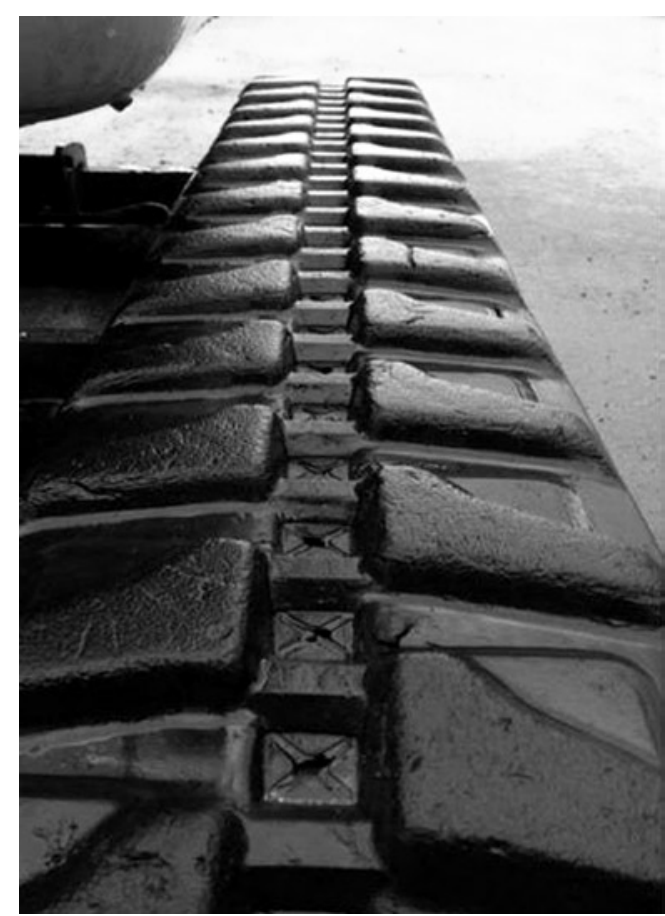

Fig. 7. The elastomeric track No. 2, the specimen in the after-operating state through the period of 1228 working hours. Numerous cracks and damages visible at the surface, the tread edges are significantly rounded and the tread is porous

The microscopic tests have shown that all the tested wires, according to recommendations of the PNEN 10323:2005 (U) standard, were made of the unalloyed pearlitic steel and the applied cold drawing process disabled achieving the high degree of plastic deformation of the $80-90 \%$ row (Fig. 10 and 11). The initial microscopic tests have not shown significant differences in

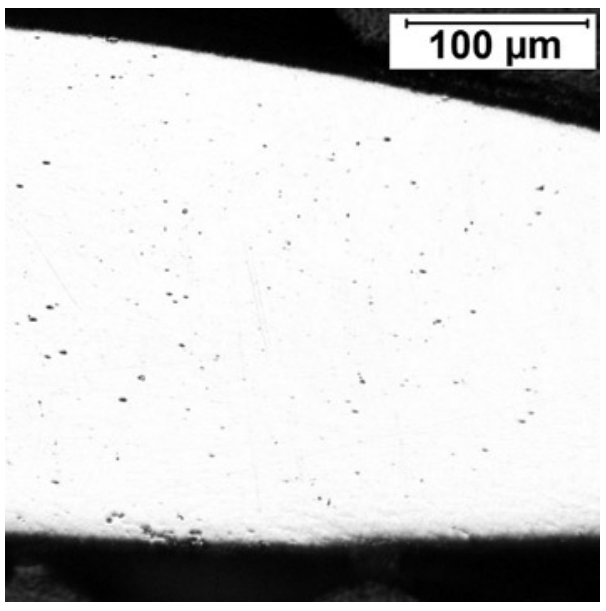

Fig. 9. Material of the cord wire from track No. 2, visible oxide non-metallic inclusions in the quantity equal to the standard 4 according to the PN-64/H-04510 standard. Non-etched state. Longitudinal section. LM

the structure of the

tested samples but further observations with application of the scanning electron microscopy have shown the clear influence of operating on structure of the tested material (Fig. 12 and 13). Results of the microstructure analysis have shown that during operation of the track chain the material of steel cord is destroyed. Presence of numerous structure discontinuities oriented in line with the plastic working of the material was observed caused by presence of non-metallic inclusions in the tested materials (Fig. 13).

Results of these studies have confirmed the Golis theories [16] on negative impact of non-metallic inclusions on strength of the cord wires, as well as the theory of Zelin [30] indicating that the main cause of cracking of the pearlitic steel subjected to operating are micro delaminations created between the cementite lamellae. The obtained results 


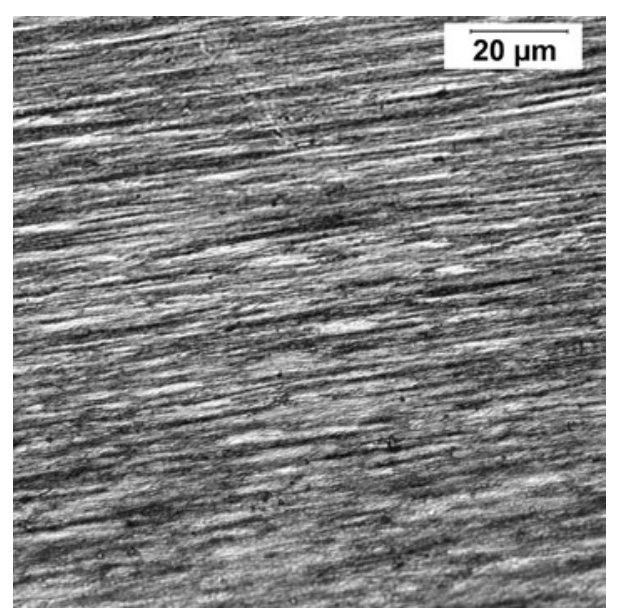

Fig. 10. Microstructure of the wire sample coming from cord of the new track No. 1. Visible strong material deformation texture amounting to about 90\%. Longitudinal section. $L M$

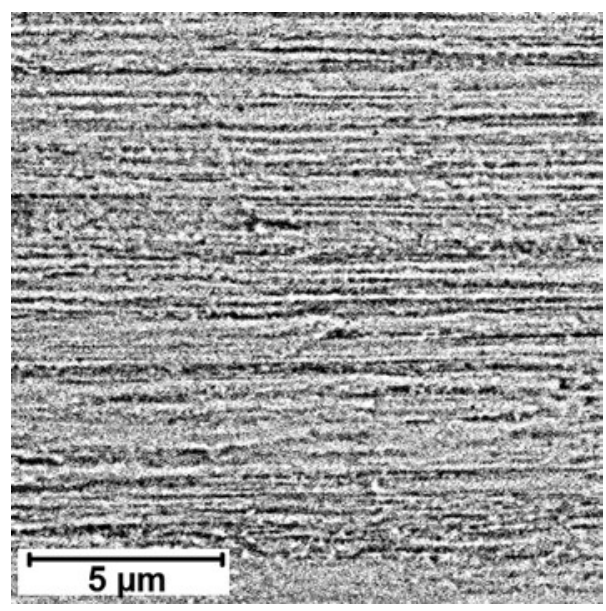

Fig. 11. Microstructure of the wire sample coming from cord of the new track No. 2 Visible strong material deformation texture amounting to about $80 \%$. Longitudinal section. $L M$

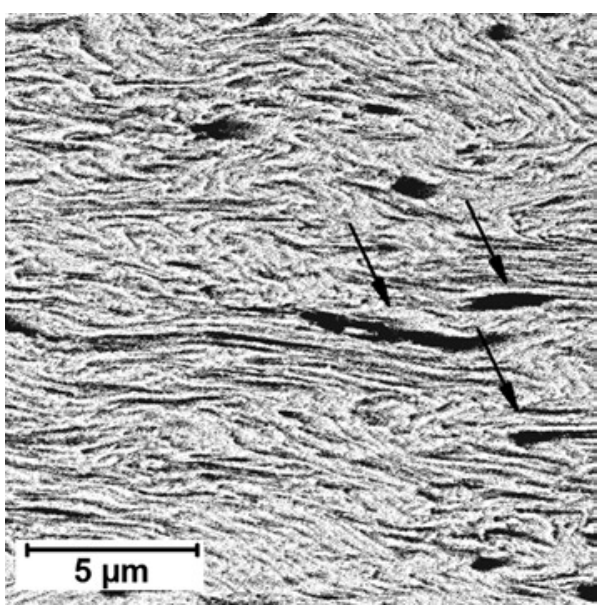

Fig. 12. Microstructure of the wire sample coming from cord of the track No. 1, not operated. Visible strong material deformation texture created as a result of cold drawing. Longitudinal section. SEM have shown that around impurities the material discontinuities are created capable of exceeding the critical size of the defect and causing the wire cracking. The process can have the following course:

- micropores are created at plastic deformation around non-metallic inclusions,

- at proceeding the plastic deformation the micro pores grow and approach each other,

- when the bridges between pores become narrow they are breaking in sequence,

- as a result of micro bridges breaking the coalescence of discontinuities follows in the direction perpendicular to the acting load,

- as a result of discontinuities coalescence the pores created around the non-metallic inclusions reach the size of the critical defect at which the cracking develops unstably and leads to the fatigue damage of a component.

The results of strength tests have shown that the structure discontinuities observed in the microscopic tests significantly influence the mechanical and technological properties of wires (Table 1). The effect of operating the elastomeric track, the specimen No. 2, is clear drop in strength properties of the wires of its cord. The tensile strength for the wire sample coming from the cord of the non-operated track No. 1 amounted to about $3430 \mathrm{MPa}$, and for the wire sample coming from the track No. $2-2050 \mathrm{MPa}$. The material is less tough, which

Table 1. Results of mechanical properties measurements for the tested wire samples.

\begin{tabular}{||c|c|c|c||}
\hline SAMPLE & $\mathbf{R m}_{\text {ś }}[\mathrm{MPa}]$ & $\mathrm{Z}_{\text {śr }}[\%]$ & $\mathbf{H V}_{\text {śr }} \mathbf{0 , 5}$ \\
\hline $\begin{array}{c}\text { WIRE FROM THE TRACK NO. } \\
\text { 1 CORD }\end{array}$ & $3430 \pm 100$ & $15 \pm 2$ & $742 \pm 20$ \\
\hline $\begin{array}{c}\text { WIRE FROM THE TRACK NO. } \\
\text { 2 CORD }\end{array}$ & $2050 \pm 100$ & $18 \pm 2$ & $621 \pm 20$ \\
\hline
\end{tabular}

Table 2. Results of the technological trials on the tested wires.

\begin{tabular}{||c|c|c||}
\hline SAMPLE & $\begin{array}{c}\text { AVERAGE NUMBER OF } \\
\text { ROTATIONS IN THE } \\
\text { TORSION TEST }\end{array}$ & $\begin{array}{c}\text { AVERAGE NUMBER OF } \\
\text { CONTRAFLEXURES IN THE } \\
\text { FLEXING TEST }\end{array}$ \\
\hline $\begin{array}{c}\text { WIRE FROM THE TRACK NO. } \\
\text { 1 CORD }\end{array}$ & $171 \pm 10$ & $103 \pm 10$ \\
\hline $\begin{array}{c}\text { WIRE FROM THE TRACK NO. } \\
\text { 2 CORD }\end{array}$ & $84 \pm 5$ & $38 \pm 5$ \\
\hline
\end{tabular}

results from the fact, that during the static tensile test the discontinuities located around the non-metallic inclusions grow in the perpendicular direction to the acting load and accelerate destruction of the wire sample.

At the same time, it has been observed in the results of the strength tests that the plasticity of the material increased. The narrowing from the value of $15 \%$ for the new specimen increased to $18 \%$ for the specimen in the after-operating state. The narrowing in the operated specimen is most probably related not to the increase in the material plasticity but with annihilation of material discontinuities observed in the microscopic tests.

The significant decrease in hardness of the material from afteroperating specimens also seems interesting. The measurements have been performed for materials collected directly from the track cord. Hardness for the wire sample from the new track was equal to 742 HV0,5, and for the wire sample from the after-operating track it dropped to the value of about 621 HV0,5 (Table 1). The hardness drop can be explained by presence of discontinuities in the structure of the tested wires. Increase in the material porosity directly converts to decrease in hardness.

As a result of the performed technological trials of unidirectional torsion and bidirectional contraflexure of the tested wires it has been found that the increase in necking observed in the previous tests on the operated specimens definitely is not related to increase in plasticity of the material (Table 2). The plasticity of the material clearly drops, the number of turns in the torsion test falls from 171 to 84 , and the number of contraflexures in the test decreases from 103 to the value of 38. Thus, this confirms the assumption that the increase of necking in the operated specimen is not related to the improvement in plasticity, but is a result of annihilation of the created material delaminations.

\section{Conclusions}

In the recent years the ever growing demand is observed for the fast and reliable transport means additionally characterised with large loading capacity. Pneumatic tires for cars, delivery trucks lorries, busses and agricultural or mining machines, or the specialist building equipment cannot be further reinforced with yarn, viscose or nylon. For strengthening tyres, track chains, conveyor belts, as well as the pressure hoses the high resistance wires made of unalloyed pearlitic steels 
are currently applied. Unfortunately, one of the problems widely discussed in the subject literature is cracking of the pearlitic steels during the operating.

Results of the fractographic tests of the defective track chain have shown that frequent breakage of the steel cord wires continuity in the general building practice is not the result of its improper operation. The fatigue character of the fracture should not be attributed to the way and time of operation but directly from the metallurgical quality of the cord wire material.

There is plenty of theories describing causes of pearlitic steel cracking during operation. According to Golis [16], the fatigue strength of the cord wires is greatly dependant on the degree of contamination of the material with non-metallic inclusions, and particularly on the content of oxides, silicates and sulfides. The Author clearly indicates that the maximum permissible content of non-metallic inclusions in the unalloyed pearlitic steel of the D75, D78, D80 and D83 grades designated for production of cord wires must not exceed the size of the standard No. 2, according to the EN 10247:2007 standard.

Microscopic observations of the cord wire material coming from the tested track chains performed in the non-etched state have shown the presence of large number of non-metallic inclusions, mainly in the form of oxides. The impurities were distributed punctually and appeared in quantities from the standard 3 to 4 according to the EN 10247:2007 standard. At the same time, results of further microscopic analysis have shown that during operation of the tracks the material of the steel cord is clearly eroding. The presence of numerous structure discontinuities was observed and the detailed microscopic analysis has shown that around the brittle oxides precipitations the micro pores are created, which with the progress in plastic deformation are growing and approach to each other reaching the ever growing sizes.

In the work of Zelin [30] it can be read that as a result of the elastic deformations the horizontal micro delaminations of the individual cementite lamellae are created. During operation the cord wires are subjected to the complex state of stresses in the elastic range, which explains the fact, that the observed structure discontinuities were oriented in parallel to the cementite lamellae arranged in bands.

The consequence of the observed structural changes in the material of the tested cord wires was the significant decrease in the strength and technological properties. The drop in the tensile strength resulted from the fact, that during the static tensile test the discontinuities located around the non-metallic inclusions are growing in the perpendicular direction to the acting load and after reaching the size of the critical defect accelerate damage of the wire sample. The same relationship explains the results of the technological tests of unidirectional torsion as well as bidirectional contraflexure. Results of both trials indicate for a decrease in the material plasticity as a result of its operating, which is the consequence of annihilations of the described material discontinuities. The decrease in hardness can also be explained by presence of discontinuities in the structure of the tested wires. The longer the material was subjected to operation the porosity of the material was growing, translating directly to the decrease in its hardness.

\section{References}

1. Adamczyk J. Inżynieria materiałów metalowych. Gliwice: Wydawnictwo Politechniki Śląskiej, 2004.

2. Ashby MF, Jones DRH. Engineering Materials: An Introduction to Microstructures Processing and Design. Oxford: Elsevier, 2005.

3. Ashby MF, Jones DRH. Engineering Materials: An Introduction to Microstructures Application and Design. Oxford: Elsevier, 2005.

4. Berisha B, Raemy C, Becker C, Hora P. Multiscale modeling of failure initiation in a ferritic-pearlitic steel, Acta Materialia, 2015; 100: 1118, https:/doi.org/10.1016/j.actamat.2015.08.035.

5. Burdziński Z. Teoria ruchu pojazdu gąsienicowego. Warszawa: Wydawnictwa Komunikacji i Łączności, 1972.

6. Cieśla M, Herian J, Junak G. Influence of pearlite morphology on creeping characteristic curves of R260 steel, Key Engineering Materials, 2014; 598: 39-44, https:/doi.org/10.4028/www.scientific.net/KEM.598.39.

7. Czabanowski R. Numeryczna analiza obciążeń wybranych elementów podwozia z gąsienicami elastomerowymi, Przegląd Mechaniczny, 2010; 7(8): 30-36

8. Czarski A, Skowronek T, Matusiewicz P. Stability of a Lamellar Structure - Effect of the True Interlamellar Spacing on the Durability of a Pearlite Colony, Archives of Metallurgy and Materials, 2015; 60(4): 2499-2503, https:/doi.org/10.1515/amm-2015-0405.

9. Danoix F, Julien D, Sauvage X, Copreaux J. Direct evidence of cementite dissolution in drawn pearlitic steels observed by tomographic atom probe, Materials Science and Engineering: A, 1998; 250(1): 8-13, https:/doi.org/10.1016/S0921-5093(98)00529-2.

10. De Knijf D. Optimization and characterization of a quenching and partitioning heat treatment on a low carbon steel, Book of Abstracts Modern Steels MS2014 Poland, 2014: 21-22

11. Dobrzański LA. Materiały inżynierskie i projektowanie materiałowe. Warszawa: WNT, 2006.

12. Embury JD, Fisher RM, The structure and properties of drawn pearlite, Acta Metallurgica, 1966; 14: 147-159, https:/doi.org/10.1016/00016160(66)90296-3.

13. Fedorko G, Molnar V, Ferková Ž, Tomašková M. Possibilities of failure analysis for steel cord conveyor belts using knowledge obtained from non-destructive testing of steel ropes, Engineering Failure Analysis, 2016; 67: 33-45, https:/doi.org/10.1016/j.engfailanal.2016.05.026.

14. Feng F. Texture inheritance of cold drawn pearlite steel wires after austenitisation, Materials Science\&Engineering, 2014; 618(A): 14-21.

15. Gavriljuk VG. Decomposition of cementite in pearlitic steel due to plastic deformation, Materials Science and Engineering, 2003; 345(A): 81-89.

16. Golis B, Błażejowski Z, Pilarczyk JW. Druty stalowe do zbrojenia opon. Częstochowa: Wydawnictwo Wydziału Metalurgii i Inżynierii Materiałowej, 1998.

17. Gridnev VN, Gavriljuk VG, Meshkov YY. Strength and plasticity of cold-worked steel. Kiev: Naukova Dumka, 1974.

18. Grygier D, Rutkowska-Gorczyca M, Jasiński M, Dudziński W. The structural and strength changes resulting from modification of heat treatment of high carbon steel, Archives of Metallurgy and Materials, 2016; 61(2B): 971-976, https:/doi.org/10.1515/amm-2016-0165.

19. Grygier D, Rutkowska-Gorczyca M. Influence of operating conditions of the steel cord on the structure and selected mechanical and technological properties of high carbon steel, International Journal of Engineering Research \& Science, 2015; 2(4): 1-6.

20. Grygier D. Analysis of the causes of damage to the wires of the steel belt of car tires, Interdisciplinary Journal of Engineering Sciences, 2016; 4(1): 45-49.

21. Ivanisenko Y, Lojkowski W, Valiev RZ, Fecht HJ. The mechanism of formation of nanostructure and dissolution of cementite in a pearlitic steel during high pressure torsion, Acta Materialia 2003; 51(18): 5555-5570, https:/doi.org/10.1016/S1359-6454(03)00419-1. 
22. Ivanisenko Y, Sauvage X. The role of carbon segregation on nanocrystallization of pearlitic steels processed by severe plastic deformation, Journal of Material Science 2007; 42: 1615-1621, https:/doi.org/10.1007/s10853-006-0750-z.

23. Izotov V.I., at. all, Influence of a pearlite fineness on the mechanical properties, deformation behavior and fracture charcteristic of carbon steel, The Physics of Metals and Metallography 2007; 106, 5.

24. Izotov VI, Pozdnyakov VA, Luk'yanenko EV, Usanova OYu, Filippov GA. Study of slightly etched fracture surface of a perlitic-ferritic steel by scanning electrom microscopy, The Physics of Metals and Metallography 2007; 103(5): 519-529, https:/doi.org/10.1134/ S0031918X07050122.

25. Knut A M, Ekh M, Brouzoulis J, Ahlström J. Modeling evolution of anisotropy in pearlitic steel during cold working, 28th Nordic Seminar on Computational Mechanics NSCM-28 Tallin 2015: 111-114.

26. Kulikowski K, Szpica D. Determination of directional stiffnesses of vehicles' tires under a static load operation, Eksploatacja i Niezawodnosc - Maintenance and Reliability 2014; 16(1): 66-72.

27. Languillaume J, Kapelski G, Baudelet B. Cementite dissolution in heavily cold drawn pearlitic steel wires Acta Materialia 1997; 45(3): 241245, https:/doi.org/10.1016/S1359-6454(96)00216-9.

28. Mendygrał Z. Encyklopedia Techniki Wojskowej. Warszawa: Wydawnictwo Ministerstwa Obrony Narodowej, 1978.

29. Sauvage X, Thily L, Blavette D. Microstructure evolution during drawing of a pearlitic steel containing 0.7 st.\% copper Scripta Materialia 2002; 46: 459-464, https:/doi.org/10.1016/S1359-6462(02)00002-7.

30. Zelin M. Microstructure evolution in pearlitic steels during wire drawing Acta Materialia 2002; 50: 4431-4447, https:/doi.org/10.1016/ S1359-6454(02)00281-1.

31. Zhang M-X, Kelly PM. The morphology and formation mechanism of pearlite in steel Material Characterization 2009; 60: 545-554.

\author{
Dominika GRYGIER \\ Wrocław University of Science and Technology \\ Department of Materials Science, Strength and Welding Technology \\ ul. Smoluchowskiego 25, 50-3720 Wrocław, Poland \\ E-mail: dominika.grygier@pwr.wroc.pl
}

